\title{
Low Birth Weight Babies Born to Mothers Admitted to Gynecology and Obstetrics Department of Dhaka Medical College Hospital
}

\author{
Nessa $Z^{1}$, Zaman $\mathbf{I}^{2}$, Ferdous $\mathbf{M}^{3}$ Rahman $\mathrm{S}^{4}$, Das $\mathrm{D}^{5}$
}

Conflict of Interest: None Received: 04-03-2018 Accepted: $08-05-2018$ www.banglajol.info/index.php/JSSMC

\section{Key Words:}

LBW, Low Socioeconomic Status, Preterm.

\begin{abstract}
Background: World health organization estimates that 25 million low birth weight (LBW) babies are born annually worldwide and 95\% occur in developing countries. Low birth weight is a major public health problem of Bangladesh. So an attempt was made to study the incidence of low birth weight $(<2.5 \mathrm{~kg})$ and also the associated risk factors of low birth weight among the new born babies born to Dhaka Medical College Hospital.
\end{abstract}

Aims: To determine the Prevalence of low weight among the babies born and to determine the relationship of low birth weight with maternal factor like maternal weight, height, gestational period, antenatal checkup, heavy physical work during pregnancy, hypertension, age of the mother and parity, in Obs. \& Gynae Department, DMCH.

Method: This descriptive cross sectional study was done in Gynecology and Obstetrics Department of Dhaka Medical College Hospital. Five hundred (500) samples were selected for the study. The study was done from $1^{\text {st }}$ January 2006 to 31 December 2006. Data processing and questionnaire are processed manually using scientific calculator and by computer using SPSS programmers version-16. All abortions, still born, gross congenital abnormalities were excluded from this study. The cut off point used for low birth weight is $2.5 \mathrm{~kg}$.

Results: A total of 500 women were interviewed. The incidence of low birth were found $21.6 \%$. Younger than 20 yrs (31.25\%) and more than 40 years (35.71\%) mother delivered more low birth weight babies. The primigravida and multigravida ( $>4$ parity) showed more low birth weight babies. Women from low socioeconomic condition produced significantly larger number of low birth weight babies as well as short stature. Low maternal height, less educated, illiterate, manual worker mother delivered more low birth weight babies. Preterm birth comprises larger number of low birth weight (LBW 35\%). Low height of new born babies also associated with low birth weight. Female babies were higher than the male babies. Preterm babies were lighter $(L B W)$ than the full term babies.

Conclusion: The study finds out the incidence of low birth babies, the figure close to the developing countries. The study revealed that maternal age, gestational age, parity, socioeconomic status, maternal weight and disease condition have strong relations with birth weight of babies. Occupation and antenatal check up also affects birth weight of babies.

[J Shaheed Suhrawardy Med Coll 2018; 10(1): 16-22] DOI: http://dx.doi.org/10.3329/jssmc.v10i1.38898
1. Dr. Zebun Nessa, Senior Consultant, Department of Obstetrics and Gynaecology, Kurmitola General Hospital, Dhaka.

2. Dr. Iffat Zaman, Senior Consultant, Department of Obstetrics and Gynaecology, Shaheed Suhrawardy Medical College and Hospital, Dhaka.

3. Dr. Menoka Ferdous, Associate Professor, Department of Obstetrics and Gynaecology, Shaheed Suhrawardy Medical College and Hospital, Dhaka.

4. Dr. Sumana Rahman, Junior Consultant, Department of Obstetrics and Gynaecology, Govt. Employees' Hospital, Fulbaria, Dhaka.

5. Dr. Debalina Das, Medical Officer, Department of Obstetrics and Gynaecology, Govt. Employees' Hospital, Fulbaria, Dhaka.

Correspondence: Dr. Zebun Nessa, Senior Consultant, Department of Obstetrics and Gynaecology, Kurmitola General Hospital, Dhaka, Mobile No.: 01922340244

\section{Introduction}

Birth weight is an important health indicator to create a healthy nation. Low birth weight is one of the most serious challenges in maternal and child health born in developed countries. Health of the baby depends on the extent of growth in the mother's womb and depends on the environment both intrauterine and extra uterine.

Human reproduction is a complex social, biochemical and physical process that is not as successful as once thought. There are several factors in mother influencing fetus or neonate. ${ }^{1}$ The risk factors related to neonatal nutritional 
status should be assessed in mother to reduce potential neonatal risks. The factors vary from one region to another and from one country to another, depending on the socioeconomic condition and environment.

LBW is defined in the $29^{\text {th }}$ World Health Assembly (WHA) in 1976 as a birth weight less than 2500gm. There are in fact only two ways in which birth weight can be influenced. One is the length of the time the foetus remains in utero and the other is the foetal growth rate. The Curtailment of either will lead to some form of prematurity, the former to pre-term birth and later to faetal growth retardation. Often the two conditions coexist in the developing world. ${ }^{2}$

Pre-maturity is defined as gestational age of less than 37 completed weeks. Small for gestational age (SGA)- the term is to designate the newborns with birth weight less than $10^{\text {th }}$ percentile or less than 2 standard deviation for the gestational age. A foetus of SGA may be constitutionally small or due to pathologic (foetal growth restriction).

It has been estimated by WHO that at least 13.7 million infants are born every year at term with LBW, representing $11 \%$ of all newborns in developing countries. This rate is approximately six times higher than in developed countries. ${ }^{3}$ Another Study shows 20.6 million LBW babies were born in 1979, most of them in developing countries. ${ }^{4}$ One third of the Indian babies are of LBW and this is attributed to maternal under-nutrition. ${ }^{5}$ It has been seen seven million LBW babies are born in India annually. ${ }^{6}$

There is lack of adequate information regarding the risk factors of low birth in Bangladesh. In many developing countries like Pakistan, Malaysia and Thailand maternal nutrition, lack of education, ignorance, physical labour during late pregnancy and poor economic status have been identified as the determinants of $\mathrm{LBW}^{7}$ As Bangladesh has similar socio- economic condition, culture and end environment it could be assumed that the same risk factors could have an impact on birth weight. Therefore it is an urgent need to explore the risk factors for LBW to reduce perinatal morbidity and mortality.

\section{Methods:}

This descriptive cross sectional study was done in Gynecology and Obstetrics Department of Dhaka Medical College Hospital. Five hundred (500) samples were selected for the study. The study was done from $1^{\text {st }}$ January 2006 to 31 December 2006. Data processing and questionnaire are processed manually using scientific calculator and by computer using SPSS programmers version-16. All abortions, still born, gross congenital abnormalities were excluded from this study. The cut off point used for low birth weight is $2.5 \mathrm{~kg}$.

\section{Results}

Table-1

Distribution of the mothers according to age (yrs) $(n=500)$

Maternal age (years) No. of patients Percentage (\%)

\begin{tabular}{lcc}
\hline$<20$ & 48 & 9.6 \\
$20-26$ & 340 & 68.0 \\
$30-39$ & 99 & 19.8 \\
$>40$ & 13 & 2.6 \\
\hline Total & 500 & 100.0 \\
\hline
\end{tabular}

Table shows the distribution of the mother according to age. Mothers of 20-29 age group were maximum (68.0\%).

Table-II

Distribution of Mothers according to parity (n-500)

\begin{tabular}{lcc} 
Parity & No. of patients & Percentage $(\%)$ \\
\hline 0 & 234 & 46.8 \\
1 & 135 & 27.0 \\
2 & 74 & 14.8 \\
3 & 37 & 7.4 \\
4 \& above & 20 & 4.0 \\
\hline Total & 500 & 100.0 \\
\hline
\end{tabular}

Table-II shows the distribution of mother according to parity. Para - ' 0 ' shows the Maximum (46.8 and Para 4 and above group show the minimum (4\%)

Table-III

Distribution of Newborns by birth weight (in $\mathrm{kg}$ ) according to antenatal check up (n-500).

\begin{tabular}{llcc} 
Category of Weight & No. of babies & Percentage (\%) & \\
\hline Low birth weight (LBW) & 1500 gm and less & 14 & 2.8 \\
& 1501 gm to 2499 gm & 94 & 18.8 \\
Normal weight & 2500 gm and above & 392 & 78.4 \\
\hline
\end{tabular}


Table-3 show the distribution of neonates according to birth weight. 1500 gm to fewer groups (Very low birth weight group) shows minimum (2.8\%) The Percentage of low birth weight ( $1501 \mathrm{gm}$ to $2499 \mathrm{gm}$ ) is $18.8 \%$. So total low birth weight is $21.6 \%$.

\section{Table-IV}

\begin{tabular}{lcccc}
\multicolumn{5}{c}{ Distribution of birth weight (in $\mathrm{kg}$ ) of newborn } \\
according to sex $(\mathrm{n}=500)$
\end{tabular}

Chi-square test, ns= not significant

Table-4 Shows relationship of newborn birth weight with sex. Male newborn were more $279(55.80 \%)$ than female newborns are $221(44.20 \%)$ table shows that female newborn are lighter in weight that means LBW among female newborn $(26.24 \%)$ than that of male $(17.92 \%)$

\section{Table-V}

\section{Distribution of birth weight (in $\mathrm{kg}$ ) according to} antenatal check up (n-500).

\begin{tabular}{lcccc}
$\begin{array}{l}\text { Antenatal Total } \\
\text { check up }\end{array}$ & $\begin{array}{c}\text { Normal weight } \\
(\mathrm{n}=392)\end{array}$ & $\begin{array}{c}\text { LBW } \\
(\mathrm{n}=392)\end{array}$ & $\begin{array}{c}\mathrm{P} \\
\text { value }\end{array}$ \\
\hline Yes & $214(45.88 \%)$ & $24(11.22 \%)$ & $190(88.78 \%)$ & $\mathrm{M}$ \\
No & $28654.2 \%)$ & $84(29.37 \%)$ & $202(70.63 \%)$ & $0.001 \mathrm{~s}$ \\
\hline
\end{tabular}

Chi-square test, $\mathrm{s}=$ significant

Table- $V$ shows relation of mother with LWB according to ANC. LWB Birth weight was significantly associated with mother who had no antenatal checkup.

\section{Table-VI}

Distribution of Neonates by Birth length (in cm) $n=500$

Length of neonates No. of Patients Percentage (\%)

\begin{tabular}{lcc}
\hline $30-39 \mathrm{~cm}$ & 29 & 5.8 \\
$40-49 \mathrm{~cm}$ & 281 & 56.2 \\
50 and above cm & 190 & 38.0 \\
\hline
\end{tabular}

Table shows distribution of neonates by birth length. 40$49 \mathrm{~cm}$ length group were maximum (56.2\%) and 30-39 cm groups were minimum $(5.8 \%)$

\section{Table-VII}

\begin{tabular}{|c|c|c|c|c|c|c|}
\hline \multirow[t]{2}{*}{$\begin{array}{l}\text { Age of the } \\
\text { nother }\end{array}$} & \multirow[t]{2}{*}{ Total } & \multicolumn{2}{|c|}{$\begin{array}{c}\text { Normal weight } \\
\quad(n=392)\end{array}$} & \multicolumn{2}{|c|}{$\begin{array}{c}\text { LBW } \\
(n=392)\end{array}$} & \multirow[t]{2}{*}{ P value } \\
\hline & & No & $\%$ & No & $\%$ & \\
\hline 9 and below & 48 & 33 & 68.75 & 15 & 31.25 & 0.114 \\
\hline $0-29$ & 342 & 277 & 80.99 & 65 & 19.01 & $\mathrm{~ns}$ \\
\hline $0-39$ & 96 & 73 & 76.04 & 23 & 23.96 & \\
\hline 0 and above & 14 & 9 & 64.29 & 5 & 35.71 & \\
\hline
\end{tabular}

Chi-square test, ns= not significant

Table shows incidence of low birth were among the age group of mothers below 19 (31.25\%) and above 40(35.71\%)

\section{Table-VIII}

Distribution of Birth weight according to parity $n=500$

\begin{tabular}{|c|c|c|c|c|c|c|}
\hline \multirow[t]{2}{*}{$\begin{array}{l}\text { Parity of } \\
\text { mothers }\end{array}$} & \multirow[t]{2}{*}{ Total } & \multicolumn{2}{|c|}{$\begin{array}{l}\text { Normal weight } \\
\qquad(n=392)\end{array}$} & \multicolumn{2}{|c|}{$\begin{array}{c}\text { LBW } \\
(n=392)\end{array}$} & \multirow[t]{2}{*}{$P$ value } \\
\hline & & No. & $\%$ & No & $\%$ & \\
\hline 0 & 236 & 177 & 75 & 59 & 25 & $0.237 \mathrm{~ns}$ \\
\hline 1 & 133 & 108 & 81.20 & 25 & 18.80 & \\
\hline 2 & 77 & 63 & 87.5 & 14 & 12.5 & \\
\hline 3 & 34 & 30 & 88.24 & 4 & 11.75 & \\
\hline 4 and above & 20 & 14 & 70 & 6 & 30 & \\
\hline
\end{tabular}

Chi-square test, ns= not significant

LBW Babies were found to be highest in parity 4 and above (30\%) and in primipara (25\%). Incidence of LBW babies declined in para $3(11.76 \%)$.

\section{Table-IX}

Distribution of birth weight (in $\mathrm{kg}$ ) and family income $(n=500)$

\begin{tabular}{|c|c|c|c|c|c|c|}
\hline \multirow[t]{2}{*}{$\begin{array}{l}\text { Family } \\
\text { status }\end{array}$} & \multirow[t]{2}{*}{ Total } & \multicolumn{2}{|c|}{$\begin{array}{l}\text { Normal weight } \\
\qquad(n=392)\end{array}$} & \multicolumn{2}{|c|}{$\begin{array}{c}\text { LBW } \\
(n=392)\end{array}$} & \multirow[t]{2}{*}{$P$ value } \\
\hline & & No. & $\%$ & No & $\%$ & \\
\hline Poor & 48 & 30 & 52.64 & 18 & 47.36 & $0.001 \mathrm{~s}$ \\
\hline $\begin{array}{l}\text { Low middle } \\
\text { class }\end{array}$ & 310 & 237 & 76.46 & 73 & 23.54 & \\
\hline Middle class & 130 & 114 & 87.70 & 16 & 12.30 & \\
\hline Rich & 12 & 11 & 91.67 & 1 & 8.33 & \\
\hline
\end{tabular}

Chi-square test, $\mathrm{s}=$ significant

Table shows low birth weight is significantly higher in poor people (47.36\%) and lowest in rich $(8.33 \%)$ 


\section{Table-X}

Distribution of neonate's birth weight according to
gestation period. $(n=500)$

Gestational age No. Normal weight LBW P

\begin{tabular}{lcccc} 
(in weeks) & & $(\mathrm{n}=392)$ & $(\mathrm{n}=392)$ & value \\
\hline$<37$ & 175 & $114(65.1 \%)$ & $61(34.9 \%)$ & $0.017 \mathrm{~s}$
\end{tabular}

37 and above $\quad 325 \quad 260(80.0 \%) \quad 65(20.0 \%)$

Chi-square test, $\mathrm{s}=$ significant

Table shows LBW was significantly lower (20\%) in term than Preterm LBW (34.9\%)

\section{Table-IX}

\begin{tabular}{|c|c|c|c|c|c|c|}
\hline \multicolumn{7}{|c|}{ Relation of mothers height \& birth weight of neonate } \\
\hline \multirow[t]{2}{*}{$\begin{array}{l}\text { Maternal } \\
\text { height in } \mathrm{cm}\end{array}$} & \multirow[t]{2}{*}{ Total } & \multicolumn{2}{|c|}{$\begin{array}{c}\text { Normal weight } \\
>2.5 \mathrm{Kg}\end{array}$} & \multicolumn{2}{|c|}{$\begin{array}{c}\text { LAW } \\
>2.5 \mathrm{~kg}\end{array}$} & \multirow[t]{2}{*}{$\mathrm{P}$ value } \\
\hline & & No & $\%$ & No & $\%$ & \\
\hline$<145$ & 50 & 37 & 74.0 & 13 & 26.0 & $0.600 \mathrm{~ns}$ \\
\hline $145-150$ & 215 & 165 & 76.74 & 50 & 23.26 & \\
\hline $151-156$ & 222 & 179 & 80.663 & 43 & 19.37 & \\
\hline$>156$ & 13 & 11 & 84.62 & 2 & 15.36 & \\
\hline
\end{tabular}

Chi-square test, $\mathrm{ns}=$ not significant

Table shows that more low birth weight (LBW) with the less height of mother. Birth weight increased with the increased height of mothers.

\section{Table-XII}

Distribution of birth weight according to maternal weight $(n=500)$

\begin{tabular}{lccccc}
$\begin{array}{l}\text { Maternal } \\
\text { weight in kg }\end{array}$ & Total & \multicolumn{3}{c}{$\begin{array}{c}\text { Normal weight } \\
>2.5 \mathrm{~kg}\end{array}$} & \multicolumn{2}{c}{$\begin{array}{c}\text { LBW } \\
<2.5 \mathrm{Kg}\end{array}$} \\
\hline$<40$ & & No. & $\%$ & No. & $\%$ \\
$40-45$ & 5 & 2 & 40 & 3 & 60 \\
$46-51$ & 26 & 15 & 57.69 & 11 & 42.31 \\
$52-57$ & 231 & 171 & 74.63 & 60 & 25.37 \\
$58-63$ & 166 & 139 & 83.73 & 27 & 16.27 \\
$64-69$ & 44 & 39 & 88.63 & 5 & 11.37 \\
70 and above & 8 & 7 & 87.50 & 1 & 12.50 \\
\hline
\end{tabular}

Table shows increased proportion of LBW babies were found in weight group below $40 \mathrm{~kg}(60 \%)$ and between 40 $45 \mathrm{~kg}(42.31 \%)$.

Patients were grading at intervals. Maximum number mothers were within at $46-57 \mathrm{~kg}$.

\section{Table-XIII}

Distribution of maternal education and birth weight
of neonate $(n=500)$

Chi-square test, $\mathrm{ns}=$ not significant

Table shows that $28 \%$ of the mothers were illiterate, they gave birth to significantly higher proportion of LBW babies $(39.29 \%)$ than educated mothers. Most of the normal birth weight ( $88.24 \%$ ) babies born to mothers who were highly educated.

\section{Table-XIV}

Distribution of Birth weight according to maternal occupation (n-500)

\begin{tabular}{lcccccc} 
Occupation & & \multicolumn{2}{c}{$\begin{array}{c}\text { Normal weight } \\
>2.5 \mathrm{~kg}\end{array}$} & \multicolumn{2}{c}{$\begin{array}{c}\text { LBW } \\
<2.5 \mathrm{Kg}\end{array}$} & P value \\
& & No. & $\%$ & No. & $\%$ & \\
\hline House Wife & 370 & 288 & 77.84 & 82 & 22.16 & $0.001 \mathrm{~s}$ \\
Service & 78 & 70 & 89.74 & 8 & 10.26 & \\
Manual holder & 38 & 21 & 55.26 & 17 & 44.74 & \\
Student & 14 & 13 & 92.86 & 1 & 7.14 & \\
\hline
\end{tabular}

Chi-square test, ns $=$ not significant

Table shows that significantly higher incidences of LBW babies in Manual worker (44.74\%) and decrease incidence in service holder groups $(10.26 \%)$

Table-XV

Distribution of mothers according to condition of health (n-500)

\begin{tabular}{lcc} 
Heath Status & $\begin{array}{c}\text { No. of } \\
\text { Mother }\end{array}$ & $\begin{array}{c}\text { Percentage } \\
(\%)\end{array}$ \\
\hline No associated disorder & 399 & 79.80 \\
High risk pregnancy & 101 & 20.20 \\
Total & 500 & 100 \\
\hline
\end{tabular}

Tables shows two groups mothers one group no associated disorder with pregnancy $(79.80 \%)$ and another group having associated disorder (High risk Group) (20.20\%). 


\section{Table-XVI}

Distribution of Birth weight of neonates among high risk mother. (n-101)

\begin{tabular}{lcccccc} 
Name of disease & \multicolumn{3}{c}{ Normal weight } & \multicolumn{2}{c}{ LBW } & P value \\
& & \multicolumn{2}{c}{$>2.5 \mathrm{~kg}$} & \multicolumn{2}{c}{$<2.5 \mathrm{Kg}$} & \\
& No. & $\%$ & No. & $\%$ & \\
\hline PET & 55 & 28 & 50.99 & 27 & 49.01 & 0.289 \\
Essential & 6 & 4 & 66.67 & 2 & 33.33 & \\
Hypertension & & & & & & \\
APH & 15 & 4 & 26.697 & 11 & 73.33 & \\
Others & 25 & 12 & 48.00 & 13 & 52.00 & \\
\hline
\end{tabular}

Chi-square test, $\mathrm{ns}=$ not significant

Among 500 mothers, 101 mothers had some associated disorder of pregnancy. LBW is more associated with APH (73.33\%) but the condition PET is more common.

\section{Discussion}

The purpose of this study was to find out the rate of low birth weight among the babies born to mother admitted in Dhaka Medical college Hospital.

Birth weight is a recognized indicator of survival and future prognosis of the new born. Low birth weight is probably the largest single factor in prenatal death throughout the world.

The frequency of Low birth weight varies throughout the world. In this study rate of LBW was found $21.6 \%$ (Table3). A Study done by Rahman Jahaara in 2005 the result was $19.5 \%,{ }^{48}$ That means almost same result. Another study done by Nahar ${ }^{49}$ on recent trends in perinatal health in south Asia showed rate of low birth babies is $23 \%$, the figure is also close to the study.

Another study was done by GM Monowar Hossain et al showed $24 \% \mathrm{LBW}^{50}$ and found that regular antennal check up was associated with low incidence of low birth weight $(11.22 \%)$ (Table-5) than that of mother who had no antenatal checkup (29.37\%) in the particular study. This result is consistent with the study done by Dr. Rashida Begum $^{51}$ and Dr. Jahannara, ${ }^{48}$ AKMA Salam et al. ${ }^{52}$ in low birth survey of Bangladesh 2003-2004.

In this study 19 years and below age group mother and 40 years and above age group showed higher incidence of low birth weight (Table-VII). Similar studies done by AKMA Salam et a1. ${ }^{52}$ Dr. Rashida Begumt ${ }^{51}$ and Dr. Rahman Jahan Ara $^{48}$ showed almost same result.

Another study done in New York in 2001-2003 by National Center for health statistics and showed increased incidence of low birth among mother of less than 20 years $(9.6 \%)$ and more than 40 years $(10.9 \%) .{ }^{53}$
The study result is also consistent with another two studies done by Hashem et a $1^{54}$ and Meyer et at. ${ }^{55}$ where they also showed that 19 years and below age group and more than 35 years age group delivered significantly lighter babies.

In this study incidence of low birth was found to be highest among parity 4 and above (30\%) (Table- 8$)$ and also it is higher in primipara. In a study done by Rashida Begum in 1993 showed multipara (4-6) had more low birth babies. ${ }^{51}$

In another study done by AKM Salam et al in 2003-2004 in Bangladesh showed high incidence of low birth weight babies among multipara and primipara. ${ }^{52}$

In this study low income and less educated group were associated with higher incidence of low birth weight babies (Table-9 \& 10). The result is consistent with the data received from medical reference of low birth weight March of dimes $2^{\text {nd }}$ May $2006 .^{56}$

K. Naznaeen 2001 also mentioned in her study that economic status has a lot of influence on pregnancy outcome. ${ }^{38}$

Nahar N.showed in her study that low birth weight babies were higher among the mother who never gone to school. 49

In this Particular study gestational age less than 37 weeks was associated with higher incidence of LBW (35\%) than that of term pregnancy (Table-10) (20\%). Similar results found in different studies like study by AKMA Salam et al. ${ }^{52}$ in 2003-2004. Hossain GM. ${ }^{50}$ Monowar at in July 2005.

In another study done by Shohely Yeamin et al. ${ }^{57}$ in Bangladesh Showed strong association of LBW and Perterm babies.

In this particular study mothers less than $40 \mathrm{~kg}$ produce more LBW and also height less than $145 \mathrm{~cm}$ produced more LBW babies (Table-11 \& 12). Nahar $\mathrm{N}$ et al. ${ }^{49}$ also found similar effect of mother's weight and height.

Different diseased condition of mother causes low birth weight babiers. In this Study PET, essential hypertension, APH was found more associated with LBW babies (Table $-16)$.

Birth weight Wikipedia of 25 April 2006 Mentioned higher Prevalence of LBW with PET ${ }^{58}$

A Study was done by Begum Rashid Showed higher incidence of low birth babies among mother having PET, Essential hyperextension and APH. ${ }^{51}$

\section{Conclusion}

The Study finds out the incidence of low birth babies, the figures are close to the developing countries. The study revealed that maternal age, gestational age, parity, 
socioeconomic status, maternal weight and disease condition have relations with birth weight of babies. Occupation and antenatal check up also affects birth weight of babies. The study was carried out to find out the relation of different maternal variables with birth weight. Based on the study findings following recommendation can be made. To reduce LBW more antenatal checkup should be ensured through mass awareness of people; less educated mother can be involved through more field visit by health workers and mass media can be utilized to disseminate the different information which has got impact on birth weight and also the effect of low birth in future life.

\section{References}

1. Current obstetrics and Gynecology Diagnisis and Treatment Lange Medical Books/MC Graw-Hill Medical Publishing Division, New York.2004,4 $4^{\text {th }}$ edition:107-8,

2. RLT Raja. Current concepts of low birth weight Indian baby. Obstetrics and Gynaecology for Postgraduates Orient Longman Ltd Madras.1994,1:273-4

3. de Onis M Blossner M Villar J Levels and pattetns of intrauterine growth retardation in developing countries Nutrition unit,WHO, Geneva, Geneva,Switzerland,1990, 212-13

4. Martorell R. Gonzalez-cossio T. Maternal Nutrition and Birth Weight .Indian J Matern Child Health 1995;6(2):43-5.

5. Rao $\mathrm{S}$ et $\mathrm{Al}$ Intake of micronutrient-rich foods in rural Indian mothers is associated with the size of their babies at birth Pune Maternal Nutrition Study Ann Trop Paediatr 1996;16(4):327-33

6. Dhar GM, Shah GN and Bhat IA, Butt N. Low Birth weight and outcome of poor socio-obstetric interaction. J Nutr 2001:131(4):1217-24.

7. UNICEF. Annual Child and Maternal Health Report UNICEF Geneva 1998;15-18.

8. Jahanara R. Socio-economic and nutritional status of mother influence neonatal outcome Department of Obstetrics influence neonatal outcome Deparment of Obstetrics and Gynaecology, National Medical College Hospital; 2005;6667.

9. Nahar N Recent trends in perinatal health in South Asia Bangladesh in Costello A Menadhar D, eds Impreving newborn infant Health in developing countries. London, Imperial College Presws, 1999.88-92

10. Monawar Hosain et al. Factors Associated With low Birth weight in Rural Bangladesh. Tropical Pediatrics ,2005.67.70

11. Rashida Begum. Incidence of low birth Weight babies in Obstetrics and Gynaecology Department,Dhaka Medical College Hospital, in a series of thousand cases.1993;56-59.

12. Salam AKMA, Haseen F, HKM Yusuf, Torlesse H National Low birth-weight survey of Bangladesh ICDDR,Periodicals; $10-15$

13. March of Dimes Low Birth weight by maternal age. Now York, 2003;1-3 (Medical Reference).

14. Hasem et al Low birth weight in Kualalumpur, Asia Oceamin J. Obetet Gynaecol, 1991;17(2):135-42
15. Meyer MB et al. Perinatal events associated with maternal smoking during pregnancy. American journal of Epidemiology 1976;103:464-476.

16. March of Dimes. Medical References: Low Birth weight 2006:1-5.

17. Nazneen K. Maternal Factors of Low Birth Weight; A study conducted in the Obstetrics and Gynaecology Department of Dhaka Medical College Hospital, Dhaka 2001.60-64

18. Yasmin S, Osrin D, Paul E, Costello A Neonatal mo of low birth weight in Bangladesh. Bull World Health Organ, 2001; 79(7): 1-10.

19. Birth weight Wikipedia, the free encyclopedia, 2006; 4-6.

20. Karim E. A longitudinal anthropometric study of motherinfant paris from Dhaka. bangladesh; 1996; 62-69.

21. Martin L. Pernoll and Cathy Mih Taylor. Nutritional requirement in Normal Pregnancy and Prenatal Care. Current Obstetrics and Gynaecologic Diagnosis and Treatment Mc Graw-Hill Company. USA. 2003; 5-7.

22. Institute of Medicine: Nutrition During Pregnancy, I. Weight gain. 2. Nutrient Supplements. National Academy Press. 1990; 15-20:

23. WHO. 1991. Maternal Anthropometry for prediction of pregnancy outcome. Bulletin of World Hlth. Ora. 1991; 69: 523-532.

24. Edib K, Ahmed K. Effect of Nutrition on Maternal Diet During Pregnancy and its Impact on Birth Weight of Babies in a low income group of Mothers in Dhaka City. Bangladesh J Nutr. 1989; 2(2): 27-32.

25, Spinillo A, Capuzzo 1: Piazzi G. Ferrai A. Morales V. DiMario M. Risk for spontaneous preteen delivery by combined body mass index and gestational weight gain patterns delivery by combined body mass index and gestational weight gain patterns. Acta Obstet Gynaecol Scand. 1998; 77: 32-36.

26. Naeye RL. Maternal body weight and pregnancy outcome Am J Clin Nutr. 1990; 52: 273-279.

27. Salas SP. Rosso P. Reduced plasma volyme and changes in vasoactive hormones in underweight pregnant women. CcRev Med Chile 1998; 126: 504-510.

28. Robinson JS. Owens. JA. DeBaro T. Lok. F. Chidzanja S. Maternal nutrition and foetal growth. In: Ward RIIT. Smith SK. Donnai D.editors. Early Foetal Growth and development. London RCOG press. 1994; 317-329.

29. Manzoor A Arif et al. Maternal Sociocultural Status: A Novel Assessment of Risk for the Birth of Small for Gestational Age, Low Birth Weight Infants. J. Obatet. Gynaecol. 1998; 24(3): 215-222.

30. Baird. D. The I: pidemiology of Prematurity. Am J. Paediatric. 1964; 65: 909-924.

31. Institute of Medicine: Nutrition during pregnancy. Weight gain and Nutrition supplements. National Academy Press.1990.

32. Abrams B. Newman V. Small for gestational birth: meternal predictors and comparisons with risk factors of spontaneous preteim delivery in the same cohort. Am J Obstet Gynaecol, 1991; 164: 785-790.

33. Begum N. Hussain T. Afridi B. et al. Effect of supplimentry feeding of pregnant women on birth weight of the newborn. Plant Food Hum Nutri 1991, 4 1: 329-336.

34. Neel NR, Alvarez JO. Maternal risk factors for low birth weight and intrauterine growth retardation in a Guatemalan population. Bull Pan Am Health Organ. 1991; 25(2): 152-65 
35. Caroline H.D. Fall et al. Micronutrient and Foetal Growth, Am J Nutr, 2001; 131(4): 1217-24.

36. Kramer, M.S. Balanced protein/energy in pregnancy (Cochrane Review). In.- The Cochrane Library, Issue 4: CD 000032. Update Software, Oxford, 2002.

37. World Health Organization, Meternal Anthropometry and Pregnancy Outcomes: a WHO collaborative study. Bull W.H.O. 1995; 73.

38. Naazneen K. Maternal Factors of Low Birth Weight: A study conducted in the Obstetrics and Gynaecology Department of Dhaka Medical College Hospital, Dhaka 2001.60-64

39. Gebre-Medhin $\mathrm{M}$ et al, Observation on-Intrauterine growth in Urban Ethiopia, Acute Paediatr. Scand. 1978; 67: $781-789$.

40. M.H. Hall. Prepregnancy and Antenatal Care, Dewhurst's Textbook of Obstetrics and Gynaecology for Postgraduates, Sixth ed. D. Keith Edmonds, Blackwell Science, 2000,

41. Naeye and Peters. Working during pregnancy: Effects on the foetus. Journal of Paediatrics, 1982; 69(6): 724-727,

42. Cinningham FG et al. Prenatal care, Willams Obstetrics, McGraw-Hill, 2001; 21 ${ }^{\mathrm{St}}$ ed; 142-145.

43. Noberega FJ et al. Anthropometry in Brazilian newborn infants: stadies of association with some maternal factors, Nestle Nutrition Workshop Series, 1989; 18: 157-164.

44. Bangladesh Demographic and Health Survey, 2000: 155-58.

45. Robert DF et al. Effect of parity on birth weight and other variables in a Tanganika Bantu Sample, Brit, J. Prev. Soc. Med, 1963; 17: 209.

46. Kalam A. "Anthropometric parameter of the newborns in Bangladesh" 2000; 135-138.

47, Sprundel M. Van Buve A. Serfiliral A, Auwera JC, Der, Meheus A and Clercol A. De. Birth weight and socioeconomic status: a study in Kigali, Rwands, International Journal of Epidemiology, 1988; 17(3): 579-581.

48. Jahanara R. Socio-economic and nutritional status of mother influence neonatal outcome. Department of Obstetrics and Gynaecology, National edical College Hospital; 2005; 66-67.

49. Nahar N. Recent trends in perinatal health in South Asia: Bangladesh In: Costello A, Manandhar D, eds. Impreving newborn infant health in developing, countries. London, Imperial College Press, 1999. 88-92

50. Monawar Hosain et al, Factors Associated with low birth weight in Rural Bangladesh. Tropical Pediatrics, 2005,67-70

51. Rashida Begum. Incidence of low birth weight babies in Obstetrics and Gynaecology Department, Dhaka Medical College Hospital, in a series of thousand cases. 1993; 56-59.

52. Salam AKMA, Haseen F, HKM Yusuf, Torlesse H. National low birth-weight anrth weicht survey of Bangladesh. ICDDR, B C, Periodicals, 2004; 10-15,

53. March of Dimes. Low birth weight by maternal age. New York, 2003; 1-3 (Medical Reference).

54. Hasem et al . Low birth weight in Kualalumpur, Asia Oceamia j.Obstet gynaecol, 1991; 17 (2):135-42

55. Meyer MB et al .perinatal events associated with maternal smoking, during pre ${ }^{\mathrm{g}}$ nancy. American journal of Epidemiology 1976; 103:464-476.

56, March of Dimes. Medical References: Low birth weight. 2006: 1-5.

57. Yasmin S, Osrin D, Paul E, Costello A. Neonatal moortality of low-birth-weight infants in Bangladesh. Bull World Health Organ, 2001; 79(7): $1-10$.

58. Birth weight- wikipedia, the free encyclopedia, 2006.4-5. 